Available for free online at https://ojs.hh.se/ JTSTB

Journal of Intelligence Studies in Business Vol 5, No 2 (2015) 22-35

\title{
The impact of CRM on QoE : An exploratory study from mobile phone industry in Morocco
}

\author{
Amine Aziza ${ }^{1}$, Mourad Oubrich $^{2}$ and Klaus Solberg Søilen ${ }^{3}$ \\ ${ }^{1}$ Institut national des postes et télécommunications (INPT), Morocco, \\ ${ }^{2}$ Madinat Al Irfane Rabat-Institutes-Morocco, \\ ${ }^{3}$ Halmstad University, Sweden \\ E-mail: oubrich@inpt.ac.ma, amineaziza10@gmail.com, klasol@hh.se
}

Received August 10, accepted October 1052015

\begin{abstract}
Today's mobile phone sector is marked by intensified competition and strong market penetration. In this environment, the carriers offer their customers a wide variety of services that are quite similar from one operator to another. These customers are always searching for a quality of experience (QoE). On one hand, operators interact with their customers through CRM practices inspired by their marketing strategies and rolled out through their procedures and technological support. On the other hand, the customers expect an extremely high quality of service (QoS) and subjectively perceive the utility and usability (Qp) of these mobile services. This paradox led us to study the impact of CRM on the customer experience (QoE) in the mobile phone industry, in this study with data from Morocco. Empirical data confirms existing theory, CRM determinants for QoE include quality of service, quality of interaction with customer, claims management and customer knowledge. However, we also found that practitioners are aware that organizations should look beyond the relationship to manage the customer experience. To this end we developed a model based on the first four CRM determinants and the findings in this study.
\end{abstract}

KEYWORDS: CRM, QoE, QoS, Qp, Mobile services, Business Intelligence, ERP 


\section{Introduction}

The field of Customer Relation Management (CRM) is linked to that of Business Intelligence (BI) in that CRM systems rely on ever greater sets of data and datamining capabilities.

Interest in CRM has begun to grow in the 1990's (Xu and al., 2002). Within the sector of information technology management research, CRM has become its own niche thanks to its relative newness and growth explosion (Lambert, 2010). According to Nguyen (2013), Dyché (2001), Greenberg (2004), Osarenkhoe and Bennani (2007), CRM allows companies to build a lasting relationship with their customers whilst constantly keeping in touch with them. According to Ejaz and al. (2013), CRM is considered as one of the best approaches to satisfy and retain customers. The results of their studies have shown that CRM has a positive impact on customer satisfaction and on customer experience which in turn directly impact customer loyalty. Our research goes in the same direction as that of Ejaz and al. (2013), but with a different vision.

Our objective is to explore the determinants of CRM and those of the quality of the customer experience in order to study their causal relationship. The customer relationship is a subject of great interest, especially in the domain of service activities/interactions due to the importance of the "supplier-customer" interface to achieve a high quality of the realization of service (QoS) (Damperat, 2005). In addition, services have now become a priority; they are by nature "moments of truth", which makes them more sensitive to good perceived quality (QP) in the exchange relationship (Giordano, 2006). Furthermore, the quality of experience (QoE) is a subjective measure of the adequacy of a service which the customer was expecting. In the literature, we found that there is little empirical research on the study and the measurement of the impact of CRM on QoE (research gap). It is important to understand the cause and effect relationship between CRM practices and (QoE) in order to establish a conceptual framework.

We begin by drawing from the literature of those two concepts, theirs definitions, theoretical foundations, models and functions. Secondly, we present the research methodology and the results of the exploratory qualitative study of thirteen CRM practitioners. In conclusion, we propose a preliminary conceptual model that links CRM to QoE.

\section{Literature review}

The customer and the service provider are found in the service relationship in two separate logics (Averous, 2004). Everyone perceives their service delivery according to their perspective and its repository. The customer repository is one of the affects, the subjectivity and the holistic cognition while as the display domain of the service provider can be defined as the technicality, occupation, objectivity and accountability (Averous, 2004). The interaction between the two perspectives is not obvious and requires efforts in terms of listening, proximity and anticipation. From this come the sensitivity and complexity of the CRM field of study and QoE for both service providers and customers respectively.

As CRM advances, so does its multidimensional character. We therefore think that to go through the CRM practices and determinants, is worthwhile by studying the link to QoE. The mobile phone industry is a major area for CRM practices. The question is how does CRM impact QoE?

\subsection{CRM}

CRM is a strategic concept which draws its basis from economic and social exchange theories and relationship marketing (Damperat, 2005). The supporters of transactional exchange paradigm as Coase (1937) and Williamson (1979) study the customer-supplier relationship in its absolute transactional sense. The paradigm of social exchange supported primarily by Hakansson (1982), raises the importance of the social relationship that promotes greater transactional exchange. Other authors such as Marion (2001), Parvatiyar and Sheth (2001), Arndt (1979) bring the notion of relational exchange that takes into account both transactional and social exchange with a concept of relationship sustainability over à long period of time. Since 2000, supporters of the new technology approach as Plakoyiannaki and Tzokas (2002), Grabner and Moedritsher (2002), Chang and Young (2007) and Coovi (2010) defend the role of technology in CRM.

CRM can be defined as a business strategy oriented towards the customer (Park and Kim, 2003). This strategy is supported by information and communication technology and aims to facilitate and improve relationships with customers (Lamparello, 2000; Mckim, 2002). Several definitions have been developed by several authors (Table $n^{\circ} 1$ ); it appears that the CRM is seen as both a business strategy and a technological process (Dionne, 2001), thus the increasing importance of Business Intelligence (BI) and Datamining. 
Table $n^{\circ}$ 1: CRM approaches

\begin{tabular}{|l|l|}
\hline CRM as a business strategy & $\begin{array}{l}\text { Parvitiyar and Sheth (2001), Buttle (2001), Thieriez (2002), Zablah and al } \\
\text { (2005), Singh and al (2003), Peppers and Rogers (2004), Peelen and al } \\
(2009), \text { Allard and Guggémos (2005), Rogers and Dorf (1999), Urbanskiené } \\
\text { and al (2008), Hobby (1999), Dalziel and al (2011), Osarenkhoe and Bennani } \\
(2007), \text { Lambert (2010). }\end{array}$ \\
\hline $\begin{array}{l}\text { CRM as a strategy supported by } \\
\text { technology }\end{array}$ & $\begin{array}{l}\text { Lamparello (2000), Mckim (2002), Crosby and Johnson (2002), Dionne } \\
(2001), \text { Ramaseshan and al (2006), Allard and Guggémos (2005). }\end{array}$ \\
\hline CRM as a technological process & $\begin{array}{l}\text { Bose (2002), Xu (2002), Missi and al (2002), Payne and Frow (2006), } \\
\text { Khanna (2001), Stone and Woodcock (2001), Frock (2000), Ryals and Knox } \\
(2001), \text { Chen and al (2009). }\end{array}$ \\
\hline
\end{tabular}

The depth and specificity of different CRM definitions can be seen in the form of CRM layers. For instance, Trepper (2000) propose three categories: operational, analytical and collaborative CRM. Collaborative CRM includes exchange channels with the customer (Chen and al., 2006), while the analytical CRM enables the analysis of information gathered (Zikmund, 2003) and finally the operational CRM, which aims to industrialize the company's daily contacts with its customers through a pre-established process (Cast, 2003; Pepper and Rogers, 2004).

According to Lambart (2010), CRM is the business process that provides the structure and the way for how customer relationships are developed and maintained. Specifically, the CRM process is divided into several stages combined with practices. These are defined by Chen and Russell (2007) as a set of actions taken by the company to retain current customers and attract potential ones. These practices include customer segmentation, database marketing, personalization and one-to-one marketing, proactive selling, cross-selling and loyalty program (Peelen and al., 2009).

While Shaw (1999) defines CRM as an interactive process for achieving the optimum balance between corporate investment and the satisfaction of customer needs to generate the maximum profit. Objectives and CRM functions are multiple; it is a way to get superior financial performance (Lambert, 2010; Boulding and al., 2005; Bohling and al., 2006), a differentiator with a competitive advantage (Almquist and al., 2002; Missi and al., 2002) and a long-lasting contact support for customer loyalty through long-term relationships (Nguyen, 2007; Greenberg, 2004; Osarenkhoe and Bennani, 2007).
CRM also allows the company to customize and improve the quality of customer service (Nguyen, 2007) and to share customers knowledge within and between offices (Nguyen, 2007) and consequently to achieve profitable growth (Greenberg, 2004) and better performance. CRM is considered a strategic approach, oriented toward processes (Lambert, 2010; Payne and Frow, 2006; Zablah and al., 2005), it's cross-functional (Lambert, 2010; Payne and Frow, 2006), a mutual value creator for the buyer and the seller (Lambert, 2010; Boulding and al., 2005; Payne and Frow, 2006).

The analysis of the most important and various CRM models that we found in the literature review allowed us to highlight some determinants (Table $\mathrm{n}^{\circ} 2$ ), where it is recognized that strategy, people, technology, and processes are all important factors in CRM (Chang, 2007).

All models which are found in the literature review are predictive, conceptual and integrators of factors which explain CRM. Our theoretical contribution will be to study the determinants of CRM and their relationship with QoE.

\subsection{QoE}

The customer experience is an interdisciplinary concept that has been the subject of research in various fields including economics, psychology and management (Qing et al., 2013). The customer experience is considered a new concept that refers to all the emotions and feelings experienced by a customer before, during and after the purchase of a product or service (Gentile et al., 2007). It is a source of satisfaction and loyalty influence (Lefranc, 2013). Pine and Gilmore (1999) were the first who studied the concept of the customer experience and they showed that the customer experience can provide be a new area of competition. 
To provide an optimal and a positive customer experience is important, seeing as it impacts customer satisfaction and creates an emotional connection with the brand. It therefore enhances customer loyalty (Gentile et al., 2007). The quality paradigm is the theoretical basis of the QoE, through disconformity theory based on the measurement of the gap between customer expectations and performance of the product or service (Oliver, 1980; Churchill and Suprenant, 1982). The American school, known as SERVQUAL (Parasuraman et al., 1985) suggests a conceptualization of perceived quality seen in ten dimensions and refined in five dimensions: reliability, helpfulness, insurance, tangibility and empathy. In comparison the Nordic School defended by Grönroos (1990) is based on the work of Swan and Combs (1976) and identify two dimensions of service quality, the technical quality (what the customer receives) and the functional quality (what the customer perceives).

Theories of psychology have also treated the customer experience including the ergonomic psychology theory in the context of humantechnology interaction that revolves around usefulness, usability and acceptability (Dillon and Morris, 1996; Tricot and al., 2003). Other psychosocial theories analyze the subjective component of the customer experience, mainly the Theory of Reasoned Action (TRA) (Fishbein and Ajzen, 1975), the Theory of Planned Behaviour
(TPB) (Ajzen, 1991) and the Interpersonal Behavior Theory (IBT) (Triandis, 1980). For Soldani et al., (2006), the term (QoE) refers to the perception of the user on the quality of a particular service. It is expressed in human feelings as "good", "excellent", "poor", etc. Soldani et al., (2006) highlight in their researcs, focused on UMTS networks, the difference between QoS and QoE, stating that the quality of service $(\mathrm{QoS})$ is inherently a technical concept. It is measured, expressed, and understood in terms of technical features, mechanisms and procedures between the user equipment and the network, which usually makes little sense for the end user. Many methods have been proposed to evaluate QoE subjectively and objectively (Xin Yu et al., 2012). QoE, is a subjective measure of the adequacy of a service compared to customer expectations. It measures the "rendering" of the use of a service and how a user perceives the conviviality of a service, the satisfaction level that comes with a service in terms of conviviality, accessibility, continuity and integrity of the service (Soldani et al., 2006).

The literature review allowed us to highlight two different approaches of QoE (Table ${ }^{\circ} 3$ ):

-The QoE as objective and subjective measure of the customer experience.

-The QoE as an evaluation of customer perception, the gap between expectations and performance. 
Table $n^{\circ}$ 2: Summary of the determinants according to different CRM models

\begin{tabular}{|c|c|c|c|}
\hline Determinant & Model & Summary Model & Author \\
\hline Strategy & $\begin{array}{l}\text { The Customer } \\
\text { Connections Ernest \& } \\
\text { Young Model }\end{array}$ & $\begin{array}{l}\text { Sign in and get closer to customers to make } \\
\text { them real partners }\end{array}$ & $\begin{array}{l}\text { Allard and Derringer, } \\
(2000)\end{array}$ \\
\hline Strategy & $\begin{array}{l}\text { The model of the IDIC } \\
\text { methodology }\end{array}$ & Identify, Differentiate, Interact, Customize & $\begin{array}{l}\text { Peppers and Rogers, } \\
(2004)\end{array}$ \\
\hline $\begin{array}{l}\text { Strategy, Process, HR, } \\
\text { Organization, Customer } \\
\text { Centric. }\end{array}$ & Balanced Scorecard & $\begin{array}{l}\text { Calculation of the performance: financial } \\
\text { perspective, perspectives related to the } \\
\text { customer, internal processes to the business, } \\
\text { organizational learning }\end{array}$ & $\begin{array}{l}\text { Kaplan and Norton, } \\
\text { (1996) }\end{array}$ \\
\hline Customer centric & $\begin{array}{l}\text { Model based on the } \\
\text { several stages of } \\
\text { customer life cycle }\end{array}$ & $\begin{array}{l}\text { - Initialization or Acquisition } \\
\text { - Maturation and rupture }\end{array}$ & Dwyer and al., (1987) \\
\hline $\begin{array}{l}\text { Customer centric, } \\
\text { Organization and culture, } \\
\text { HR, Process, Technology }\end{array}$ & The CRM Value Chain & $\begin{array}{l}\text { Primary level are centered on customer and } \\
\text { support conditions are focused on } \\
\text { profitability }\end{array}$ & Buttle, (2001) \\
\hline $\begin{array}{l}\text { Strategy } \\
\text { Process } \\
\text { Technology }\end{array}$ & $\begin{array}{l}\text { The model of the } \\
\text { strategic framework } \\
\text { CRM }\end{array}$ & $\begin{array}{l}\text { - The development strategy } \\
\text { - The Information Management } \\
\text { - The value creation process } \\
\text { - The process of performance evaluation } \\
\text { - Multi-Channel Integration }\end{array}$ & $\begin{array}{l}\text { Payne and Frow, } \\
\text { (2006) }\end{array}$ \\
\hline Organization et HR & $\begin{array}{l}\text { Service and profit chain } \\
\text { model }\end{array}$ & $\begin{array}{l}\text { There is a link between satisfaction and } \\
\text { employee motivation and customer } \\
\text { satisfaction }\end{array}$ & $\begin{array}{l}\text { Heskett and al , } \\
\text { (1994) }\end{array}$ \\
\hline Strategy & $\begin{array}{l}\text { An integration framework } \\
\text { of CRM implementation } \\
\text { strategy }\end{array}$ & $\begin{array}{l}\text { - Analysis } \\
\text { - Formulation and strategy selection } \\
\text { - Implementation of the strategy }\end{array}$ & $\begin{array}{l}\text { Osarenkhoe and } \\
\text { Bennani, (2007) }\end{array}$ \\
\hline Process & $\begin{array}{l}\text { Measures framework of } \\
\text { CRM Impact on } \\
\text { economic added value }\end{array}$ & $\begin{array}{l}\text { Impact on sales, cost of goods sold, total } \\
\text { expenditures, inventory investment, other } \\
\text { current assets, and investment in fixed assets }\end{array}$ & Lambert, (2010) \\
\hline $\begin{array}{l}\text { Strategy } \\
\text { Culture } \\
\text { Contexte }\end{array}$ & $\begin{array}{l}\text { Conceptual framework } \\
\text { for overall CRM }\end{array}$ & $\begin{array}{l}\text { Macro Factors: internal and external to the } \\
\text { company } \\
\text { Micro factors: marketing activities, customer } \\
\text { focus, buying behavior. } \\
\text { Conceptual framework for overall customer } \\
\text { relationship management }\end{array}$ & $\begin{array}{l}\text { Ramaseshan and al., } \\
\text { (2006) }\end{array}$ \\
\hline $\begin{array}{l}\text { Technology } \\
\text { Strategy } \\
\text { HR }\end{array}$ & $\begin{array}{l}\text { Challenges for overall } \\
\text { customer relationship } \\
\text { management }\end{array}$ & $\begin{array}{l}\text {-Technology } \\
\text {-Economy and market } \\
\text {-Regulatory Framework } \\
\text {-Culture and Social }\end{array}$ & $\begin{array}{l}\text { Ramaseshan and al, } \\
(2006)\end{array}$ \\
\hline $\begin{array}{l}\text { Process } \\
\text { HR } \\
\text { Technology }\end{array}$ & CRM Implementation & $\begin{array}{l}\text { The successful implementation of a CRM } \\
\text { requires an integrated and balanced } \\
\text { approach of technology, processes and } \\
\text { human resources }\end{array}$ & $\begin{array}{l}\text { Injazz and Popovich, } \\
(2003)\end{array}$ \\
\hline
\end{tabular}


Table n 3: QoE Approaches

\begin{tabular}{|c|c|}
\hline \multicolumn{2}{|l|}{ QoE } \\
\hline $\begin{array}{l}\text { Objective and } \\
\text { subjective measure }\end{array}$ & $\begin{array}{l}\text { (Kilkki, 2008), (Rehman } \\
\text { and al., 2011), (Xin and al., } \\
\text { 2012), (Mitra and al., (Hassenzahl, } \\
\text { 2011), (Chen and El Zarki, } \\
\text { 2008), (Chen } \\
\text { 2011). }\end{array}$ \\
\hline $\begin{array}{l}\text { - Assessment of } \\
\text { customer perception } \\
\text { - Gap between } \\
\text { expectations and } \\
\text { performance }\end{array}$ & $\begin{array}{l}\text { (Rehman and al., 2011), } \\
\text { (Fiedler and al., 2010), } \\
\text { (Chumpitaz and Swaen, } \\
\text { 2004), (Gentile and al., } \\
\text { 2007), (Lefranc, 2013), } \\
\text { (Johnston and Kong, } \\
\text { 2011), (Johnson and } \\
\text { Mathews, 1997). }\end{array}$ \\
\hline
\end{tabular}

\section{Epistemology and research methodology}

This research aims to explain the relationship between CRM practices and the quality of the customer experience (QoE). To sort out this relationship, we position ourselves within a positivist perspective based on the hypotheticodeductive approach. This epistemological position aims to draw a state of the art to build an adequate theoretical framework for this relationship and derive hypotheses that will bring forward a more representative reality (Miles and Huberman, 1991) through a qualitative study in order to explore the main determinants of CRM practices and the most significant factors in the quality of the customer experience.

In this paper, we present an exploratory qualitative study in terms of CRM practices in the mobile phone industry. The sample consists of about $60 \%$ of practitioners among telephony mobile operators, $16 \%$ of vital service provider and $24 \%$ of SS2I. Interviews were carried out according to an interview guide constructed at the base of the determinants of CRM identified from the literature review summarized it in Table ${ }^{\circ} 2$.

For data analysis, we collected, recorded and transcribed data by Transcriber Application. To this end, we mobilized the content analysis method (Bardin, 1977). Moreover, with the Sphinx Lexica, we treated and coded all the answers and we analyzed the verbatim by following the method of parsing (syntactic unit) and semantic (Andreani and Conchon, 2005). Following this analysis, we got answer segments that we have grouped around recurring key ideas that revolve around the five factors: Strategy, Process, Organization, Personnel and Technology.
For greater objectivity, we opted for a statistical analysis of key ideas through coding categories (Andreani and Conchon, 2005), marking out the words forming these categories. With the method of multiple correspondence analyses (MCA) ${ }^{1}$, we have five sets of contingencies tables that intersect in multiple matrices, as variables for each practitioner. At the end we treated statistically the contingency tables by XLSTAT for the study:

- The rate of inertia $^{2}$ which measures the practitioner's opinions dispersion around the variables (key ideas) from the center of gravity (CRM determinant) as two factorial axes.

- The factorial axes are the most active components of CRM determinant and around which the variables and observations disperse. These are the main terms or combinations formed by matching variables to observations and the observations of each variable (absence, presence, recurrence).

- The variance of the distribution of the practitioner's notices by qualitative variable associated with the variance of the distribution of variables per practitioner around factorial axes to represent the eigenvalue. ${ }^{3}$

- The total inertia rate is the sum of the eigenvalues. When the inertia ratio is high, it means that there is a strong dependence between variables and observations, if the total inertia ratio is low, the variables are independent of observations.

- The cumulative percentage of inertia indicates the level of inertia or dispersion and can explain the categories of profiles alike. In our research we have practitioners who share the same point of view about the correspondence of the CRM determinants.

\section{Results and interpretations}

The analysis of the CRM determinants components by the MCA method allowed us to identify for each determinant, the Total Inertia ratio, the Eigenvalues, Inertia percentage and percentage of Accumulated Inertia.

\subsection{The CRM strategy Determinant}

CRM practitioners mostly confirm the existence of a customer-centric CRM strategy and perceive CRM as a software tool. They argue that the CRM goals are: quality of customer service (QoS), satisfaction, customer loyalty and profitability of the company. Other objectives were mentioned but with less

\footnotetext{
1 The Multiple Correspondence Analysis (MCA) is a statistical method to study at least the association between two variables, observations (CRM practitioners) and terms of observational variables (absence, presence, recurrences).

${ }^{2}$ Inertia ratio is the sum of the projected variances.

${ }^{3}$ This is the projected variance of inter-qualitative variables for a variance inter-practitioners.
} 


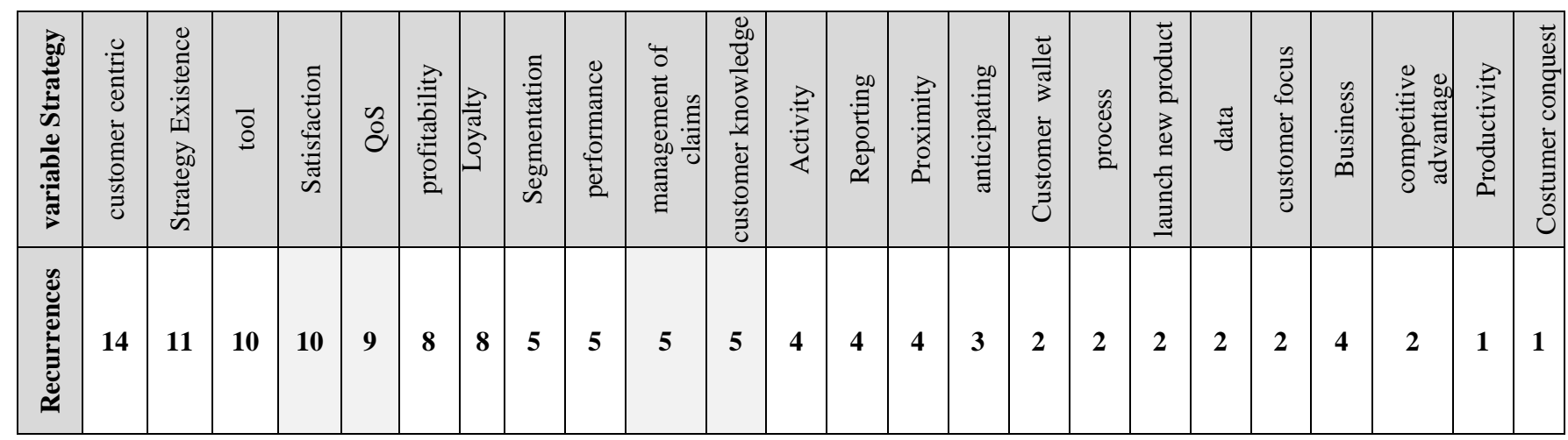

frequency, for example performance, segmentation, complaints management, customer knowledge.

The inertia of the key components of CRM strategy is 3,923. This is the highest value of the calculated rate. It indicates that there is a high practitioner's opinions concentration around the CRM strategy variable and its perception as an information technology tool. It's focus is on a customer-oriented approach, segmentation and claims management means, satisfaction etc. This concentration is measured around the gravity center of all CRM strategy components with the first three eigenvalues $\mu=0.492, \mu=0.376, \mu=0.318$. These values are close together and involve a high association between correspondences of practitioners opinion concerning the CRM strategy formulated by the variables listed in Table ${ }^{\circ} 4$.

\subsubsection{Eigenvalues, inertia percentage and percentage of accumulated inertia:}

For table $\mathrm{n}^{\circ} 5$ we have:

-The first line represents the rank of the factorial axis considered, $\mathrm{p}=23$ factorial axes,

- The second line shows the eigenvalues of the matrix associated with each axis,
- The third line gives the inertia ratio explained by the axes,

- The last line gives the cumulative inertia ratio (that is to say, explained the subspace formed by the axis and the previous).

The first tree values together account for over $30 \%$ of the total inertia opinions of practitioners according to the CRM strategy determinant (point cloud), so we can therefore consider other significant factorial axes that represent a combination of correspondences (variables strategy and practitioners). We can extend the factorial space to F13 which shows over $77 \%$ of the total inertia of the point clouds.

\subsection{The CRM process Determinant}

The practitioner's descriptions of the CRM process allowed us to deduce a perceptual schema CRM process. This scheme focuses on the phase and the quality of interaction with customer, customer data collection stage, qualification of customer data and integration of multi-channel communication with CRM.

\begin{tabular}{|c|c|c|c|c|c|c|c|c|}
\hline & F1 & F2 & F3 & F4 & F5 & F6 & F7 & F8 \\
\hline Own value & 0,492 & 0,376 & 0,318 & 0,280 & 0,253 & 0,227 & 0,198 & 0,188 \\
\hline Inertia (\%) & 12,542 & 9,579 & 8,106 & 7,142 & 6,446 & 5,775 & 5,055 & 4,801 \\
\hline \multirow[t]{2}{*}{ \%accumulated } & $12,542 \quad 2$ & 22,121 & 30,227 & 37,369 & 43,815 & 49,590 & 54,645 & 59,446 \\
\hline & F9 & F10 & F11 & $\mathrm{F} 12$ & $\mathrm{~F} 13$ & F14 & F15 & F16 \\
\hline Own value & 0,166 & 0,147 & 0,144 & 0,131 & 0,124 & 0,113 & 0,098 & 0,094 \\
\hline Inertia (\%) & 4,232 & 3,743 & 3,674 & $\begin{array}{l}3,335 \\
74,43\end{array}$ & 3,153 & $\begin{array}{l}2,874 \\
80,45\end{array}$ & 2,501 & 2,396 \\
\hline \multirow[t]{2}{*}{ \%accumulated } & 63,679 & 67,422 & 271,095 & $5 \quad 1$ & 77,584 & $4 \quad 8$ & 82,959 & $\begin{array}{l}95,356 \\
\end{array}$ \\
\hline & F17 & & F18 & F19 & $\mathrm{F} 20$ & $\mathrm{~F} 21$ & $\mathrm{~F} 22$ & $\mathrm{~F} 23$ \\
\hline Own value & 0,090 & & ,088 & 0,084 & 0,081 & 0,078 & 0,077 & 0,077 \\
\hline $\begin{array}{c}\text { Inertia (\%) } \\
\%\end{array}$ & 2,283 & & 252 & 2,138 & 2,071 & 1,979 & 1,961 & 1,961 \\
\hline accumulated & 87,638 & & $9,890 \quad 92$ & 92,029 & 94,100 & 96,078 & 98,039 & 100,000 \\
\hline
\end{tabular}


The determinant CRM process is in the second position with inertia ratio of 2.6. The analysis of CRM process asymmetric graphic components and observations shows that there are three different categories of profiles but closely spaced. The majority of practitioners category which recognizes the existence of the CRM process confirms its efficiency and describes it as a series of phases: customer interaction stage, customer data collection stage, qualification and treatment of data customers stage, quality interaction with the customer, billing, claims management, through procedures and certifications that enact the script and interaction with the costumer in order to satisfy and offer them the best QoS.

Also there is a class of practitioners who focuses on respect of charters, CRM procedures and scripts, the quality of customer interaction and multi-channel integration with communication channels and finally another group who perceive CRM process through the interaction with the customer stage, customer data collection stage and the multi-channel integration with the communication channels in the CRM.

Thanks to ISO certification standards, charters, scripts and quality procedures, the CRM process is considered efficient and cover among other aspects of the company's business, billing and claims management. The efficiency of the different CRM processes respectively depends on: targeted training around the CRM function and delivery by the team which in most cases is conducted to work in networks, the sensitization and assessment system of CRM human resources and their professional skills.

The first three eigenvalues are: $\mu=0.413, \mu=$ $0.348, \mu=0.316$, they are close together which explains that there is a significant association between concepts, listed in Table $n^{\circ} 6$ to explain the CRM process.

Table $n^{\circ}$ 6: Semantic recurrences related to CRM process according to practitioners.

\begin{tabular}{|l|c|}
\hline \multicolumn{1}{|c|}{ Concepts } & $\begin{array}{c}\text { Number of } \\
\text { occurrences }\end{array}$ \\
\hline Interaction with the customer phase & 18 \\
\hline Integration multi channels with CRM & 16 \\
\hline Qualification and customer data processing & 15 \\
\hline Efficiency procedure & 11 \\
\hline Collecting customer data phase & 10 \\
\hline Claims Management & 9 \\
\hline Quality of interaction with the customer & 8 \\
\hline Billing & 8 \\
\hline Charter, user guide, scripts Respect & 7 \\
\hline Quality of Service & 5 \\
\hline ISO certification, internal procedures & 5 \\
\hline Satisfaction & 3 \\
\hline Existence of CRM procedures & 6 \\
\hline absence of CRM procedures & 1 \\
\hline
\end{tabular}

\begin{tabular}{lllllll}
\hline & $\mathrm{F} 1$ & $\mathrm{~F} 2$ & $\mathrm{~F} 3$ & $\mathrm{~F} 4$ & $\mathrm{~F} 5$ & $\mathrm{~F} 6$ \\
\hline Own value & 0,413 & 0,348 & 0,316 & 0,297 & 0,249 & 0,196 \\
$\begin{array}{l}\text { Inertia (\%) } \\
\%\end{array}$ & 15,902 & 13,387 & 12,149 & 11,422 & 9,571 & 7,548 \\
accumulated & 15,902 & 29,289 & 41,439 & 52,860 & 62,432 & 69,980 \\
\hline & $\mathrm{F} 7$ & $\mathrm{~F} 8$ & $\mathrm{~F} 9$ & $\mathrm{~F} 10$ & $\mathrm{~F} 11$ & $\mathrm{~F} 12$ \\
\hline Own value & 0,187 & 0,155 & 0,138 & 0,114 & 0,099 & 0,086 \\
\hline Inertia (\%) & 7,211 & 5,978 & 5,312 & 4,370 & 3,823 & 3,327 \\
\hline $\begin{array}{l}\text { \% } \\
\text { accumulated }\end{array}$ & 77,191 & 83,169 & 88,480 & 92,850 & 96,673 & 100,000 \\
\hline
\end{tabular}

Table $n^{\circ}$ 7: The 12 factorial axes

4.2.1 Eigenvalues, inertia percentage and percentage of accumulated inertia:

For table $\mathrm{n}^{\circ} 7$ we have:

- The factorial axis rank is $p=12$,

- The first 3 values together account for over $41 \%$ of the total inertia practitioners opinions in relation with CRM process determinant. We can think about other factor axes that are significant and represent the combination of correspondences (process variable and practitioners). We can extend the factorial space to F5 with more than $62 \%$ of the total inertia of the point clouds.

\subsection{The CRM organization determinant}

The CRM function is considered by a minority of practitioners as a call center job. CRM is a project 
that is often supported by top management but without a specific function in the organization. In addition, it is located halfway between the marketing function, the business function, the customer service function and sometimes the Information System Direction (ISD).

The determinant of the CRM organization gives us an idea about the CRM position inside the service provider's organization. Its inertia ratio is 2.286 and it comes third after the CRM process determinant.

We found that there are three positions categories with average dispersion. There is a category of practitioners where the CRM is positioned at the top management level and largely deviates from the two other categories. The second category positions CRM into the sales function level with an average concentration of observations around this variable. The third category consists of practitioners who share their opinions around a CRM organizational position that integrates the marketing function, IS Direction, management services and customers, n-1 levels of top management and the sales office.

The first three eigenvalues are $\mu=0.413$,

$\mu=0.315, \mu=0.281$, they are less close together which explains that there is a less significant association between the variables representing CRM Organization listed in Table $n^{\circ} 8$.

Table $n^{\circ}$ 8: Semantic recurrences according to the CRM organization

\begin{tabular}{|l|c|}
\hline \multicolumn{1}{|c|}{ Concept } & $\begin{array}{c}\text { Number of } \\
\text { occurrences }\end{array}$ \\
\hline Top management & 9 \\
\hline Business function & 8 \\
\hline Existence of responsible unit & 7 \\
\hline Management services and clients & 6 \\
\hline Marketing function & 5 \\
\hline Customer Relationship Centre & 4 \\
\hline Level N-1 & 3 \\
\hline IS Direction & 3 \\
\hline Marketing Officer & 3 \\
\hline Networks Team & 3 \\
\hline Claims Management Centre & 2 \\
\hline Sales Management & 2 \\
\hline
\end{tabular}

4.3.1 Eigenvalues, inertia percentage and percentage of accumulated inertia:

\begin{tabular}{lllllll}
\hline & $\mathrm{F} 1$ & $\mathrm{~F} 2$ & $\mathrm{~F} 3$ & $\mathrm{~F} 4$ & $\mathrm{~F} 5$ & $\mathrm{~F} 6$ \\
\hline & 0,41 & 0,31 & 0,28 & 0,22 & 0,20 & 0,17 \\
Own value & 3 & 5 & 1 & 5 & 4 & 9 \\
& 18,0 & 13,7 & 12,2 & 9,85 & 8,91 & 7,84 \\
Inertia (\%) & 77 & 76 & 89 & 7 & 4 & 8 \\
\%accumul & 18,0 & 31,8 & 44,1 & 54,0 & 62,9 & 70,7 \\
ated & 77 & 53 & 43 & 00 & 14 & 62 \\
\hline
\end{tabular}

\begin{tabular}{lllllll}
\hline & F7 & F8 & F9 & F10 & F11 & F12 \\
\hline Own value & 0,149 & 0,133 & 0,124 & 0,094 & 0,087 & 0,081 \\
$\begin{array}{l}\text { Inertia (\%) } \\
\%\end{array}$ & 6,526 & 5,817 & 5,404 & 4,132 & 3,801 & 3,560 \\
accumulated & 77,288 & 83,105 & 88,508 & 92,640 & 96,440 & 100,000 \\
\hline
\end{tabular}

Table $n^{\circ} 9$ : The 12 factorial axes

- We considered twelve factorial axis $\mathrm{p}=12$,

- The first tree values together account for over $44 \%$ of the total inertia practitioners opinions related to the CRM Organization determinant. Also we can take into account other factorial axes. We can extend the factorial space to F5 with more than $62 \%$ of the total inertia of the point cloud.

\subsection{The CRM technology Determinant}

The technological component of CRM comes in the fourth position with 1,81 as total inertia ratio. There are several categories of profiles relatively dispersed according to their CRM expectations but concentrated into two categories. The first category of practitioners use the software CRM (Integrated CRM software in the ERP, CRM-SQL, VOCALCOM, NOBELSYSTEM, Software GRC, EFBI Platform, Microsoft Dynamic CRM, SAP CRM, Saleforces, Zoho, SugarCRM) and other software managements such as ELAG and business management software. They are interested in reports generated by the CRM and indicators that these reports occur.

While the second category consists of a minority of practitioners who are aware of the importance of the CRM software and dashboards they generate, they don't use it in their own activities because they are involved as SS2I; in other words as, assistant project manager in CRM solutions integration.

These results reflect the overall vision of a recent study published by the Gartner Institute for the year 2014 "Magic Quadrant for Business Intelligence and Analytics," especially for the point of operational and decision-making ability of CRM that are raised 
in this report. The report also highlights that "historical leaders of the CRM market: Oracle, Microsoft, IBM and SAP are this year the big losers" with a speed loss on the clear quadrant.

The first three eigenvalues of CRM technology determinant are $\mu=0.360, \mu=0.234, \mu=0.193$. They are less close which explains that there is less and less of an important combination between concepts that represent the CRM technology that we list in table $\mathrm{n}^{\circ} 10$.

Table $n^{\circ}$ 10: Semantic recurrences on CRM technology according to practitioners

\begin{tabular}{|l|l|}
\hline Concept & $\begin{array}{l}\text { Number } \\
\text { occurrences }\end{array}$ \\
\hline Specific software & $\mathbf{9}$ \\
\hline Other software & $\mathbf{6}$ \\
\hline Dashboard & $\mathbf{2}$ \\
\hline Performance report & $\mathbf{5}$ \\
\hline Accessibility and Flexibility & $\mathbf{8}$ \\
\hline $\begin{array}{l}\text { Excellent experience, satisfaction and } \\
\text { customer knowledge }\end{array}$ & $\mathbf{7}$ \\
\hline Managements indicators & $\mathbf{6}$ \\
\hline Performance indicators & $\mathbf{6}$ \\
\hline Sales report & $\mathbf{4}$ \\
\hline Marketing campaign report & $\mathbf{4}$ \\
\hline Periodic reports & $\mathbf{4}$ \\
\hline Independence & $\mathbf{4}$ \\
\hline Profitability & $\mathbf{4}$ \\
\hline Performance & $\mathbf{4}$ \\
\hline Predictors & $\mathbf{3}$ \\
\hline Reliability & $\mathbf{3}$ \\
\hline Management report & $\mathbf{2}$ \\
\hline Sale force automating & $\mathbf{3}$ \\
\hline Zoning report & $\mathbf{2}$ \\
\hline
\end{tabular}

According to the data analysis, the most cited CRM tools are the specific solutions (SAP CRM, Saleforces, Zoho, SugarCRM, Microsoft Dynamic CRM, CRM-SQL software Vocalcom, Nobelsystem) or other management solutions. They are either integrated into ERP, operated in open source configuration, internally developed or developed with the help of a professional integrator. nnn

We noted the positive feedback toward practitioners dashboards generated by their CRM. The periodic sales tables, marketing campaigns and performance are the most cited and produce management indicators, predictive and performance indicators. They are deployed in the decision making on several levels. However, it must be said that CRM practitioners still expect more accessibility, flexibility, reliability and independence of their information technology solutions to impact the customer experience and to know them better in order to satisfy them.

4.4.1 Own values, inertia percentage and percentage of accumulated inertia:

\begin{tabular}{lllllll}
\hline & $\mathrm{F} 1$ & $\mathrm{~F} 2$ & $\mathrm{~F} 3$ & $\mathrm{~F} 4$ & $\mathrm{~F} 5$ & $\mathrm{~F} 6$ \\
\hline Own value & 0,360 & 0,234 & 0,193 & 0,161 & 0,158 & 0,156 \\
Inertia (\%) & 19,875 & 12,943 & 10,666 & 8,898 & 8,754 & 8,638 \\
\%accumulated & 19,875 & 32,818 & 43,484 & 52,383 & 61,137 & 69,775 \\
\hline \multicolumn{7}{c}{} \\
& $\mathrm{F} 7$ & $\mathrm{~F} 8$ & $\mathrm{~F} 9$ & $\mathrm{~F} 10$ & $\mathrm{~F} 11$ & $\mathrm{~F} 12$ \\
\hline \multirow{2}{*}{ Own value } & 0,124 & 0,114 & 0,096 & 0,078 & 0,076 & 0,059 \\
Inertia (\%) & 6,840 & 6,313 & 5,312 & 4,321 & 4,201 & 3,239 \\
\%accumulated & 76,615 & 82,927 & 88,239 & 92,560 & 96,761 & 100,000 \\
\hline
\end{tabular}

Table $n^{\circ} 11:$ The 12 factorial axes

- We consider 12 factorial axes,

- The first tree values together account for more than $43 \%$ of the total inertia of the point cloud. Beyond third factor, the difference between values becomes insignificant, so we limit ourselves to F3.

\subsection{CRM Human Resources Determinant}

The determinant of human resources is the latest one with a total inertia ratio of 1,286 . It means that practitioners disagree with a wide dispersion about the key components of Human Resources namely staff skills, training on CRM and sensitization and assessment systems developed around CRM. The analysis of asymmetric graph of variables and observations showed a big gap between the profiles of practitioners and high data dispersion.

The first three eigenvalues of the HR CRM are $\mu$ $=0.707, \mu=0.327, \mu=0.252$. They are not at all close, which explains that there is a weak association between concepts that represent the Human Resources as a determinant of CRM.

Table $n^{\circ}$ 12: Semantic recurrences related to Human Resources CRM according to practitioners

\begin{tabular}{|l|l|}
\hline Concepts of & $\begin{array}{l}\text { Number } \\
\text { occurrences }\end{array}$ \\
\hline Staff Skills & 12 \\
\hline CRM training System around & 30 \\
\hline $\begin{array}{l}\text { Sensitization } \\
\text { CRM }\end{array}$ & 10 \\
\hline Assessment and control System & 16 \\
\hline
\end{tabular}


4.5.1 Own values, inertia percentage and percentage of accumulated inertia:

\begin{tabular}{llll}
\hline & F1 & F2 & F3 \\
\hline Own value & 0,707 & 0,327 & 0,252 \\
$\begin{array}{l}\text { Inertia (\%) } \\
\%\end{array}$ & 54,957 & 25,442 & 19,601 \\
accumulated & 54,957 & 80,399 & 100,000
\end{tabular}

- The first line represents the rank of the considered factorial axis, $p=3$ factorial axes,

- The first tree values together account for $100 \%$ of the total inertia practitioners opinions according to HR CRM determinant. We can limit our analysis to the first factor with $54 \%$ of inertia and for more significations connections we can also consider the second axis with more than $80 \%$ of the total inertia of the point clouds

\section{Conclusion}

To conclude, CRM is a strategic choice for enterprises and mainly for mobile phone service providers. They have to guide the overall strategy toward the costumer. In other words, it is essential to rethink the organization and business structure around customer service, train and develop management and IT skills related to CRM, implement an effective process and support it with technology. The objective is to offer consequently a quality customer experience in the use of services across CRM practices. Furthermore, we understand with evidence that interactive links between the determinants of CRM and the determinants of the quality of the customer experience (QoE) exist. On one hand, the semantic analysis of CRM determinants brings up the determinants that we found in the literature review of the quality of customer experience, like quality of service, quality of interaction with customer, claims management and customer knowledge. And on the other hand, it turns out that practitioners are aware that we should look beyond the relationship to manage the customer experience to satisfy and retain thereafter. To this end, we will propose a preliminary model built around the first four CRM determinants taking into account the results obtained (Figure $\mathrm{n}^{\circ} 1$ ) of the exploratory study and our conclusion.

Figure 1: CRM determinants

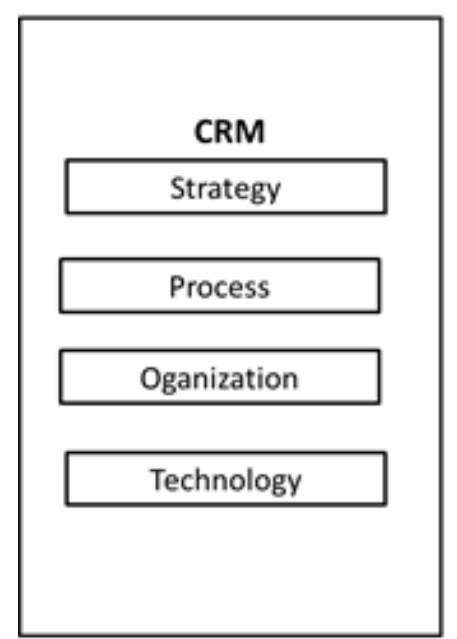

Our research has been limited by the problem to interview professionals and the double burden of transcription and coding the dialectal language to foreign language. The next stage of our research is to study the determinants of QoE in order to develop a conceptual model of the relationship between CRM and QOE.

\section{References}

Arndt, J. (1979), “Toward a concept of domesticated markets", Journal of Marketing, vol. 43, pp. 6975 .

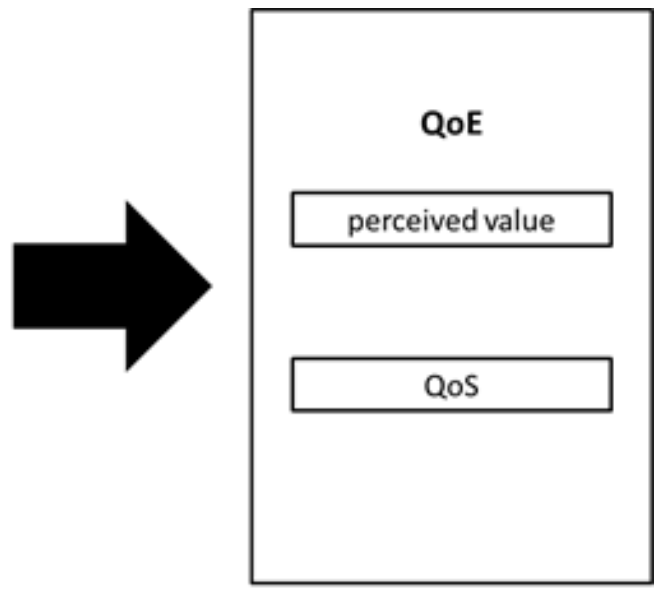

Ajzen, I. (1991), "The theory of planned behavior," Organizational Behavior and human Decision Processes, 50, 179-211.

Almquist, E., Heaton, C. and Hall, N. (2002), "Making CRM make money", Marketing Management, Chicago, 11, 3, 16-21.

Andreani, J. and Conchon, F. (2005), "Methods of analysis and interpretation of qualitative studies", Marketing Conference Proceedings 2005, www.escp-eap.net.

Averous, B. and Averous, D. (2004), "manage and measure the quality of service, the method CYQ», INSEP consulting editions, p5. 
Allard, P. and Guggémos, P.A. (2005), "CRM: the key to success", organization Edition, Paris2005.

Allard, P. and Derringer, D. (2000), "Customer relationship strategy", Dunod, Paris

Alireza, F. (2010), "The Critical Success Factors for Implementation of CRM and Knowledge Management in a Work Setting”. 3PGCIC, 140148.

Bardin, L. (1977), "Content analysis", PUF

Bose, R. (2002), "Customer relationship management: key components for IT success", Industrial management \& Data systems, Vol. 102, 89-97.

Boulding, W., Staelin, R. and al. (2005), “A Customer Relationship Management Roadmap: What Is Known, Potential Pitfalls, and Where to Go", Journal of Marketing, Vol. 69, No. 4, pp. 155-166.

Bohling, T. and al. (2006), "CRM Implementation: Effectiveness Issues and Insights", Journal of Service Research, 9, 184194.

Buttle, F. (2001), "The CRM value Chain", Marketing Business, volume 96, p 52-55.

Chang, H. and Young, G. (2007), "Critical Factors and Benefits in the implementation of customer Relationship Management", Total Quality Management, Vol. 18, N5, 483-508, July 2007.

Chen, J-S. and Russell, K.H.C. (2007), "The effects of Mobile Customer Relationship Management on customer Loyalty: Brand image Does Matter", Proceeding of the $40^{\text {th }}$ Annual Hawaii International conference on system sciences, IEEE 2007.

Chen, J-S., Yen, H-J-R. and Li, E. (2009), "Measuring CRM Effectiveness: Construct Development, Validation and Application of a Process-Oriented Model, Total Quality Management and Business Excellence", SCCI journal, vol. 20(3).

Chen Y-H., Su, C-T. and Sha, D.Y.(2006), "Linking innovative product development with customer knowledge: a data-mining approach", Technovation, Volume 26, Issue 7, July 2006, Pages 784-795.

Chen, P. and El Zarki, M. (2011), "Perceptual View Inconsistency: An Objective Evaluation Framework for Online Game Quality of Experience (QoE)", IEEE 2011.

Chumpitaz, R. and Swaen, V. (2004), "The perceived quality as a determinant of customer satisfaction in business-to-business. An empirical study in the telephony sector", Marketing Research and Applications, 19, 2, 31-52.

Coase, R. H. (1937), "The Nature of the Firm," Economica, 4,386-351.

Crosby, L.A. and Johnson, S.L. (2002), "High performance marketing in the CRM era", Marketing Management, pp. 10-11

Churchill, G.A. and Suprenant, C. (1982), “An Investigation into the Determinants of Customer Satisfaction", Journal of Marketing Research,
Vol. 19, No. 4, Special Issue on Causal Modeling, pp. 491-504

Coovi, B. (2010), " Customer lifecycle management: proposal of a conceptual model of evaluation of the use of CRM software ", Portfolio Management. Auvergne University, ClermontFerrand I, French.

Dwyer, F.R., Schurr, P.H. and Oh S. (1987), "Developing buyer -seller relationship", Journal of marketing, 51, 11-27.

Dalziel, N., Harris, F. and Laing, A. (2011), "A multidimensional typology of customer relationships: from faltering to affective", International Journal of Bank Marketing, Vol. 29 Iss: 5, pp.398 - 432

Dillon, A., Morris, M.G. (1996), "User acceptance of new information technology: theories and models", Annual Review of Information Science and Technology, 14(4):3-32

Damperat, M. (2005), "Customer relationship approaches: evolution and nature, "1st Conference of Research in Marketing, IRIS Lyon IAE.

Dyché, J. (2001), "The CRM Handbook: A business guide to customer relationship management", Boston: Addison - Wesley.

Dionne, M. (2001), "To understand the CRM: The logic of Russian dolls", available on www.crmodyssey.com.

Ejaz, R. and al. (2013), "Impact of CRM Practices on Customers Behaviors", International Journal of Business and Management Invention ISSN, Volume 2 Issue 7, PP.79-88.

Fiedler and al. (2010), "The Psychology of Implicit Emotion Regulation: A Special Issue of Cognition", Cognition and emotion, volume 25, issue3.

Fishbein, M. and Ajzen, I. (1975), "Belief, attitude, intention, and behavior: An introduction to theory and research", Reading, MA, Addison-Wesley.

Greenberg, P. (2004), "CRM at the speed of light, essential customer strategies for the $21 \mathrm{st}$ century". New York: Mc Graw-Hill/ Osborne.

Gentile, C. and al. (2007), "How to Sustain the Customer Experience: An overview of Experience Components that co-create Value with the Customer", European Management Journal, Vol. 25, N5, pp.395-410.

Giordano, J.L. (2006), "The perceived quality approach", Organization editions, p12.

Grönroos, C. (1990), "Service management and marketing: managing the moments of truth" In Service Competition, Lexington Books, New York.

Grabner, K.S. and Modritscher, G. (2002), "Alternative approaches toward measuring CRM performance", 6th Conference on Relationship Marketing and Customer Relationship Management, Atlanta, 9-12.

Hassenzahl, M. (2008), "User Experience (UX): Towards an experiential perspective on product quality", University of Koblenz-Landau, 
Germany Media City, Åbo Akademi University, Finland, www.marc-hassenzahl.de

Huberman and Miles. (1991), "Analyse des données qualitative: recueil de nouvelles méthodes", Boeck University, Brussels.

Hobby, J. (1999), "Looking After the One Who Matters", Accountancy Age, 28-30.

Heskett, J. L. and al. (1994), "Putting the ServiceProfit Chain to Work", Harvard Business Review, 72(2), pp. 164-174

Hakansson, H. (1982), "International marketing and purchasing of industrial goods: An interaction approach", Wiley, New York.

Injazz, J. C. and Popovich, K. (2003), "Understanding customer relationship management (CRM): People, process and technology", Business Process Management Journal, Vol. 9 No. 5, 2003, pp. 672-688

Johnson, C. and Mathews, B. P. (1997), The influence of experience on service expectations, International Journal of Service Industry Management 8(4): 290-305.

Johnston, R. and Kong, X. (2011), "The customer experience: a road-map for improvement, Managing Service Quality". Emerald Group Publishing Limited, Vol. 21, No.1, pp. 5-24.

Kilkki, K. (2008), "Quality of Experience in Communications Ecosystem", Journal of Universal Computer Science, vol. 14, no. 5 (2008), 615-624

Kutner, S. and Cripps J. (1997), "Managing the customer portfolio of healthcare enterprises", The Healthcare Forum Journal, 40(5), 52-54.

Kaplan, R.S. and Norton D.P. (1996), "The Balanced Scorecard: Translating Strategy into Action", Boston: Harvard Business School Press.

Khanna, S. (2001), "Measuring the CRM ROI: Show Them Benefits," available at http://www.crmforum.com.

Lefranc, E. (2013), "Management of Customer Experience: Beyond satisfaction surveys, the extent of the experience," Thesis: June 2013.

Lambert. D. M, (2010), "Customer relationship management as a business process", USA, Journal of Business \& Industrial Marketing, Volume 25, Number 1, 4-17.

Lamparello, D. (2000), "Doing more for the right customers", Bank Systems and Technology, New York, 37, 1, R10-R13.

Laghari, K.R. (2012), "On quality of experience (QoE) for multimedia services in communication ecosystem". Institut National des Télécommunications, 2012. English, NNT : 2012, TELE0008.

Laghari et al. (2011), "QoE aware Service Delivery in Distributed Environment", Advanced Information Networking and Applications Workshops, Biopolis, Singapore, March 22 - 25, 2011.

Leo Y.M., Alan C.B. and Frederick H.K. (2005), "CRM: conceptualization and scale development", European Journal of Marketing Vol. 39 No. 11/12, 2005 pp. 1264-1290.
Missi, F., Alshawi, S. and Irani, Z. (2002), "Customer Relationship Management in the EBusiness: Data integration issues", 7th Conference of the Association Information Management, Hammamet, Tunisia, 19.

Mitra , K. and al. (2011), "A probabilistic contextaware approach for quality of experience measurement in pervasive systems", $S A C$ '11 Proceedings of the 2011 ACM Symposium on Applied Computing, Pages 419-424

Marion, G. (2001), "Relationship marketing is there?" Marketing Decisions, $\mathrm{n}^{\circ} 22$.

Mckim, R. (2002), "Information: The newest currency", Target Marketing, Philadelphia, 22, 7, 36-37.

Nguyen, T.H and al. (2007), "strategies for successful CRM Implementation", information, management \& computer security, vol 15, 102 115.

Nguyen, B. and Mutum, D.S. (2013), "A review of customer relationship management: successes, advances, pitfalls and futures", Business Process Management Journal, Vol. 18 No. 3, pp. 400419, Emerald Group Publishing Limited.

Osarenkhoe, A. and Bennani, A. (2007). "An exploratory study of implementation of customer relationship Management strategy".Business Process Management Journal, vol13, 139-164.

Oliver, R. (1980), "A Cognitive Model of the antecedents and consequences of satisfaction Decisions", Journal of Marketing Research, Vol. $17, \mathrm{~N}^{\circ} .4$, pp. 460-469.

Peelen, E. and al., (2009), "An empirical study into the foundations of CRM Success", Journal of Strategic Marketing,Vol. 17, N $6,453-471$.

Parasuraman, A., Zeithaml, V. and Berry,L. (1985), "Alternative scales for measuring service quality: A comparative assessment based on psychometric and diagnostic criteria", Journal of Retailing, Volume 70, Issue 3, Pages 201-230

Plakoyiannaki, E. and Tzokas, N. (2002), "CRM: a capabilities portfolio perspectives", Journal of Data base marketing, 9, 3, 228-237.

Parvatiyar and Sheth. (2001), "Customer Relationship Management: Emerging Practice, Process, and Discipline", Journal of Economic and Social Research, 3(2), pp1-34.

Pine, BJ. and J.H. Glimore. (1999), "Welcome to the experience economy", Harvard business review, 76: p. 97-105.

Payne, A. and Frow, P. (2006), "Customer relationship management: from strategy to implementation", Journal of Marketing Management, 22, 135-168.

Park, C.H and Kim, Y.G. (2003), "A framework of dynamic CRM: linking marketing with information strategy", Business Process Management Journal, Vol. 9 No. 5.

Peppers. D, Rogers. M, (2004), "Managing Customer Relationship: a strategic framework", Hoboken, N.J: John Wiley \& Sons

Qing, Y. Z and al. (2013), "Empirical study on the Relation between Customer Experience and 
Behavioral Intentions in Tibetan cultural theme hotel", International Conference on Service Science, IEEE.

Ramaseshan, B. Bejou, D. Jain, S. Mason, C. and Pancras, J. (2006), "Issues and Perspectives in Global Customer Relationship Management", Journal of Service Research, 9, 2, 195-207.

Rogers, M. Dorf, B. (1999), "The one-to-one in practice", organization Editions.

Ryals, L and Knox, S. (2001), "cross Functional issues in The Implementation of relationship marketing Through customer relationship Management (crm)", European Management Journal, 2001, Vol. 19 No.5, pp.534-42

Stone, M. and Woodcock, N. (2001), "Defining CRM and Assessing its Quality," Successful Customer Relationship, Marketing", eds. London: Kogan.

Swan, J.E. and Combs, L.J. (1976), "Product performance and consumer satisfaction: a new concept", Journal of Marketing, Vol. 40, April, pp. 25-33.

Shaw, R. and Reed, D. (1999), "Measuring and Valuing Customer Relationships: How to Develop the Measures that drive profitable CRM strategies", Business Intelligence, p4.

Saint Cast. N, (2003), "Organize your customer relationships today: The CRM new way", Maxima Editions.

Singh and al., (2003), "CRM: Conceptualization and Scale development", European Journal of Marketing, Vol. 39 No. 11/12, 2005 pp. 12641290.

Soldani, D and al. (2006), "QoS and QoE Management in UMTS Cellular Systems", John Wiley \& Sons edition, p2-4.
Triandis, H. C. (1980), "Values, attitudes and personal behavior, Beliefs, attitudes and values", University of Nebraska Press.

Tricot, A., Plégat-Soutjis, F., Camps, J. F., Amiel, A., Lutz, G., and Morcillo, A. (2003), "Utility, utilisability, acceptability: interpret the relationship between the three dimensions of evaluation", Environnements Informatiques pour l'Apprentissage Humain. Strasbourg.

Trepper, C. (2000), "Match your CRM tool to your business model". Information week, Vol, 15, 74.

Thieriez .A, (2002), "Un CRM européen pour la banque ?", Revue Banque stratégie, $\mathrm{n}^{\circ} 193$, pp.569-582.

Urbanskienè. R, Žostautienè. D, Chreptavičienè, V. (2008), "The Model of Creation of Customer Relationship Management (CRM) System", Engineering Economics, The Economic Conditions Of Enterprise Functioning. No 3 (58).

Williamson, O. E. (1985), "The economic institutions of capitatlism", The Free Press, New York.

Xin, Y. and al. (2012), "No-reference QoE Prediction Model for Video Streaming Service in 3G Networks", IEE 2012.

$\mathrm{Xu}, \mathrm{Y}$. and al. (2002), "Adopting Customer Relationship Management Technology”, Industrial management \& Data systems, vol. 102, 442-452.

Zablah, A.R., Bellenger, D.N., and Johnston, W.J. (2005), "Customer Relationship Management Implementation Gaps", Journal of Personal Selling \& Sales Management, 279-295.

Zikmund, W.G., Mc Leod. R. Jr and Faye. G.W. (2003), "Customer Relationship management: integrating marketing strategy and information technology", Hoboken, N. J.: Wiley. 